\title{
Efficacy of Different Plant Extract on Reducing Seed Borne Infection and Increasing Germination of Collected Rice Seed Sample
}

\author{
Mansur Ahmed ${ }^{1}$, Mehbub Hossain ${ }^{1}$, Kamrul Hassan ${ }^{2, *}$, Chandra Kanta Dash $^{2}$ \\ ${ }^{1}$ Department of Plant Pathology, Bangladesh Agricultural University, Mymensingh-2202 \\ ${ }^{2}$ Department of Entomology, Sylhet Agricultural University, Sylhet-3100 \\ *Corresponding Author: shishir244@gmail.com
}

Copyright (C) 2013 Horizon Research Publishing All rights reserved.

\begin{abstract}
Thirty six rice seed samples of varieties BR6, Pajam and Joya were collected from Parshuram upazila, Feni district of Bangladesh and nine seed-borne fungi were detected from these seed samples. The identified fungi were Fusarium oxysporum, F. moniliforme, Bipolaris oryzae, Alternaria padwickii, Curvularia lunata, Aspergillus flavus, Aspergillus niger, Penicillium sp. and Nigrospora oryzae. Five different plants extracts viz. garlic, allamanda, neem, chirata and bishkatali with two dilutions $(1: 1 \& 1: 2)$ were tested for seed treatment. Garlic extract (1:1) dilution found best for three varieties which successfully reduced seed-borne infection and also increased seed germination up to $68.39 \%$ over control. Neem (1:1) and chirata (1:1) extracts also increased seed germination up to $66.09 \%$ and $67.81 \%$, respectively. Based on the present study, it may be concluded that among the five plant extracts with two dilutions (1:1 \& 1:2), garlic (1:1) is most effective in controlling seed-borne fungal flora of rice followed by neem (1:1) and chirata (1:1) extract.
\end{abstract}

Keywords Plant Extracts, Varieties, Seed Germination and Infection

\section{Introduction}

Rice (Oryza sativa) is the staple food of Bangladeshi people and it constituted about $90 \%$ of the total food grain production [1]. It covers about 75 percent of the total cultivable land in Bangladesh [2]. The average world yield of rice is 3.84 tons/ha [2], but the average yield of rice in Bangladesh is only $2.52 \mathrm{t} \mathrm{ha-}^{-}{ }^{1}[3]$. So the average per hectare production of rice in Bangladesh is extremely low as compared to other rice growing countries of the world. Seed is a common carrier of plant pathogens. It acts as the primary source of many diseases. Most of the major diseases of rice are seed-borne [4]. Rice suffers from more than 60 different diseases. In Bangladesh, 43 diseases are known to occur on the rice crop. Among these diseases 27 are seed-borne of which 14 are of major importance. Fungi are the principal organisms associated with seed in storage. Of all the seed-borne diseases of rice, 22 are caused by fungi [5]. The most destructive seed-borne fungal diseases of rice are Brown spot (Bipolaris oryzae), Blast (Pyricularia oryzae), Sheath rot (Sarocladium oryzae), Sheath blight (Rhizoctonia solani), Leaf scald (Microdochium oryzae), Seed rot and Seedling blight (Bipolaris oryzae, Sclerotium rolfsii and Fusarium spp.), Grain spot (Curvularia lunata, Nigrospora oryzae, Phoma glumarum, and Cladosporium sp.). Fungi associated with discoloured rice seed resulted in poor germination and vigour and cause diseases to emerged seedling or growing plants [6] [7] weight loss [8]and loss of germination and seedling vigor [9].

There are many constraints responsible for low yield of rice in Bangladesh. Most of the diseases of rice are seed-borne. In Bangladesh, approximately 2.5 million tons of rice worth more than Tk. 12000 million is lost annually due to diseases caused by seed-borne pathogens [10]. In our country farmer's saved seeds are the main source of seeds for rice cultivation, but the farmers do not maintain the seed health properly that resulting heavy infestation by the fungi, particularly during hot and humid seasons and cause deterioration of quality and viability of seeds. These seeds results in reduced germination rate and transmit pathogens from seed to seed bed and ultimately cause field diseases. Reduction in yield and quality loss of grains of rice ranges from a trace to total crop loss depending on the inoculum density, pathogen aggressiveness, environmental conditions, cultivar susceptibility and interaction with other cultural parameters [11]. This cost farmers a huge amount of money in terms of reduced productivity and cost of control. Evidently, there is a need to increase the yield and improve the seed health and quality of the crop by controlling seed-borne fungal pathogens. Among the control practices used, seed treatment is one of the effective technique to 
eliminate seed-borne inocula which prove the 'arsenal' of plant pathology in now equipped with most sophisticated ammunitions to wage war on the unscrupulous pathogens, which are many and deceitful. Treatments of seed should be done as a routine practice as it is a cheap insurance against possible disasters at a later stage [12].Various methods have been practiced to control these pathogens. Use of plant extracts against plant disease is however, a recent approach to plant disease control. It helps to avoid environmental pollution by chemicals. Successful use of plant extracts in controlling fungal pathogens has been demonstrated by a number of authors [13] [14][15] [16] [17]. Though plant extracts have been used in controlling seed-borne infection in certain crops, their efficacy in controlling seed-borne infections of fungal pathogens in rice seeds has not yet been critically evaluated. In Bangladesh considerable work has been done on seed health and seed quality of rice by different researchers in the region of Bogra, Gazipur, Comilla, Barisal, Jessore, Sylhet, Habigonj, and Mymensingh ([18] [19] [20] [21] [22] . However, information about the farmers' stored rice seed of Parshuram upazila, Feni district of Bangladesh is not available. In view of the above facts, the present study was under taken in laboratory conditions with seed samples collected from Parshuram upazila, Feni district of Bangladesh to record the germination of seed samples and to control the fungi in the seeds with different plant extracts.

\section{Materials and Method}

The experiment was carried out at the Seed Pathology Centre (SPC) and MS Laboratory of the Department of Plant Pathology, Bangladesh Agricultural University (BAU), Mymensingh.Three rice varieties selected for the study were BR6, Pajam and Joya .The experiment was conducted following Completely Randomized Design (CRD) with three replications. A total of 36 rice seed samples were collected from farmers of Porshuram Upazila of Feni District, Bangladesh.Twelve seed samples were collected from different part of the upazila for each rice variety. The samples were enclosed in paper bags with proper labeling, brought to the SPC laboratory and kept in the refrigerator at 5 $\pm 1^{\circ} \mathrm{C}$ until used for subsequent studies.Five different plant species namely Garlic, allamanda, neem, chirata and bishkatali collected from different areas of Bangladesh Agricultural University, Mymensingh campus were used in this study. The Particulars of plants which are used for seed treatment is given below:

\begin{tabular}{|c|c|c|c|c|c|}
\hline S1.No. & Local name & Scientific name & Family & Plant & Dilutions \\
\hline 1. & Garlic & Allium sativum & Alliacene & Clove & $1: 1$ and $1: 2$ \\
\hline 2. & Allamanda & $\begin{array}{c}\text { Allamanda } \\
\text { Cathartica }\end{array}$ & Apocynaceae & Leaf & $1: 1$ and $1: 2$ \\
\hline 3. & Neem & $\begin{array}{c}\text { Azadirachta } \\
\text { indica }\end{array}$ & Meliaceae & Leaf & $1: 1$ and $1: 2$ \\
\hline 4. & Chirata & Swertia & Gentianaceae & Leaf & $1: 1$ and $1: 2$ \\
\hline 5. & Bishkatali & $\begin{array}{c}\text { Polygonum } \\
\text { hydropiper }\end{array}$ & Polygonaceae & Leaf & $1: 1$ and $1: 2$ \\
\hline
\end{tabular}

\subsection{Preparation of Plant Extracts}

The collected plant parts were chopped after cleaning in running tap water. The extracts were prepared by crushing the plant parts or clove in a blender with distilled water in $1: 1$ ratio (eg. 1:1=100 gm plant material crushed in $100 \mathrm{ml}$ water) and 1:2 ratio (eg. 1:2=100 gm plant material crushed in 200 $\mathrm{ml}$ water) [23]. The extracts were filtered through cheese cloth. The extracts thus obtained were kept in a refrigerator at $4^{\circ} \pm 1$ until use.

\subsection{Seed Treatment with Plant Extracts}

Selected seed samples of rice were treated following dipping method. The seeds were dipped in 1:1 and 1:2 dilutions for 1 hour in previously prepared garlic cloves, allamanda, neem, chirata and biskatali leaf extracts. After 1 hour, plant extracts were drained out from the petridishes. The treated seeds were allowed to be dried up on filter paper for some time and were tested following the standard blotter method [24] to observe the growth of different fungal colonies on the seeds. For each treatment 300 seeds with three replications were placed on six petridishes.

\subsection{Treatments Employed}

A total of eleven treatments (with one control) were used in the experiment are as follows:

\begin{tabular}{|c|}
\hline $\mathrm{T}_{0}=$ Control \\
$\mathrm{T}_{1}=$ Garlic extract $(1: 1)$ \\
$\mathrm{T}_{2}=$ Neem extract $(1: 1)$ \\
$\mathrm{T}_{3}=$ Bishkatali extract $(1: 1)$ \\
$\mathrm{T}_{4}=$ Allamanda extract $(1: 1)$ \\
$\mathrm{T}_{5}=$ Chirata extract $(1: 1)$ \\
$\mathrm{T}_{6}=$ Garlic extract $(1: 2)$ \\
$\mathrm{T}_{7}=$ Neem extract $(1: 2)$ \\
$\mathrm{T}_{8}=$ Bishkatali extract $(1: 2)$ \\
$\mathrm{T}_{9}=$ Allamanda extract $(1: 2)$ \\
$\mathrm{T}_{10}=$ Chirata extract $(1: 2)$
\end{tabular}

\subsection{Statistical Analysis}

The data collected from the experiment were analyzed for test of significance and compared the treatment means following Completely Randomized Design (CRD) by using Duncan's Multiple Range Test (DMRT) at 5\% level of probability.

\section{Result and Discussion}

\subsection{Effect of Plant Extracts on Seed Germination of Three Rice Varieties}

In this experiment five different plant extracts were used 
in controlling seed-borne fungi of rice. In case of variety BR6 the highest germination (91.67\%) was found when the seeds were treated with garlic extract (Allium sativum) @ 1:1 dilution and it increased germination by $67.68 \%$ over control (Table 1 and Plate 2). Among the other extracts neem (1:1) and chirata (1:1) also increased germination by $59.74 \%$ and $46.94 \%$, respectively over control (Plate 2). This is an agreement with the findings of ISTA [25] who found garlic extract was superior in terms of reducing seed-borne infections by Alternaria spp., Bipolaris sorokiniana, Curvularia lunata, Fusarium spp. of wheat to other extracts followed by ginger and neem. In case of variety Pajam, the highest germination $(97.33 \%)$ was found when the seeds were treated with garlic extract (Allium sativum) @ 1:1 dilution and chirata (1:1) and it increases germination (67.81\%) over control (Table 3 and Plate 2). Here, Garlic (1:2), chirata (1:2), bishkatali (1:1) and bishkatali (1:2) also increased germination by $64.36 \%, 60.91 \%, 58.05 \%$ and $61.50 \%$, respectively (Plate 2). This is an agreement with the findings of Rahman et., al [26] who found neem and garlic extracts were more effective against Bipolaris oryzae at 1:1 dilution.Ahmed [27] reported that seed treatment with Allamanda leaf extract at 1:1 dilution effectively increased seed germination of egg plants and tremendously decreased nursery diseases. Another researcher, Howlader [28] reported that neem leaf extracts were significantly reduced seed-borne fungal diseases.This is also a partial agreement with the findings of Mondall et., al [29]. They found that seed treatment with the garlic extract, neem, gagra, vatpata, Bishkatali leaf extracts reduced seed-borne prevalence and increased germination percentage of wheat seeds. Among them garlic and neem bark gave better results. Khan and Kumar [30] observed that bishkatali, garlic, ginger and neem extract were effective against seed-borne Curvularia lunata, Fusarium spp. of wheat. Ahmed [27] observed that neem and garlic extracts at 1:1 dilution were effective against Bipolaris oryzae.

Table 1. Effect of plant extracts (1:1 and 1:2) on germination of rice seeds (BR6)

\begin{tabular}{|l|c|c|}
\hline \multicolumn{1}{|c|}{ Treatments } & $\begin{array}{c}\text { Seed Germination } \\
(\%)\end{array}$ & \multicolumn{1}{|c|}{$\begin{array}{c}\text { Germination } \\
\text { increase over } \\
\text { control (\%) }\end{array}$} \\
\hline $\mathrm{T}_{0}=$ Control & \multicolumn{2}{|c|}{$54.67 \mathrm{i}$} \\
\hline $\mathrm{T}_{1}=$ Garlic $(1: 1)$ & $91.67 \mathrm{a}$ & 67.68 \\
\hline $\mathrm{T}_{2}=$ Neem(1:1) & $87.33 \mathrm{c}$ & 59.74 \\
\hline $\mathrm{T}_{3}=$ Bishkatali(1:1) & $70.00 \mathrm{~h}$ & 28.04 \\
\hline $\mathrm{T}_{4}=$ Allamanda(1:1) & $78.00 \mathrm{e}$ & 42.67 \\
\hline $\mathrm{T}_{5}=$ Chirata(1:1) & $80.33 \mathrm{~d}$ & 46.94 \\
\hline $\mathrm{T}_{6}=$ Garlic(1:2) & $88.67 \mathrm{~b}$ & 62.19 \\
\hline $\mathrm{T}_{7}=$ Neem(1:2) & $76.00 \mathrm{f}$ & 39.02 \\
\hline $\mathrm{T}_{8}=$ Bishkatali(1:2) & $76.33 \mathrm{f}$ & 39.62 \\
\hline $\mathrm{T}_{9}=$ Allamanda(1:2) & $70.00 \mathrm{~h}$ & 28.04 \\
\hline $\mathrm{T}_{10}=$ Chirata(1:2) & $73.33 \mathrm{~g}$ & 34.13 \\
\hline
\end{tabular}

Data presents the mean of three replications
Three hundred seeds were tested for each sample

Figure with common letters did not differ significantly at $5 \%$ level by DMRT

Table 2. Effect of plant extracts (1:1 and 1:2) on germination of rice seeds (Joya)

\begin{tabular}{|c|c|c|}
\hline Treatments & $\begin{array}{c}\text { Seed } \\
\text { Germination (\%) }\end{array}$ & $\begin{array}{c}\text { Germination } \\
\text { Increase over control } \\
(\%)\end{array}$ \\
\hline $\mathrm{T}_{0}=$ Control & \multicolumn{2}{|c|}{$58.00 \mathrm{f}$} \\
\hline $\mathrm{T}_{1}=$ Garlic $(1: 1)$ & $97.67 \mathrm{a}$ & 68.39 \\
\hline $\mathrm{T}_{2}=$ Neem(1:1) & $96.33 \mathrm{a}$ & 66.09 \\
\hline $\mathrm{T}_{3}=$ Bishkatali(1:1) & $82.00 \mathrm{e}$ & 41.38 \\
\hline $\mathrm{T}_{4}=$ Allamanda(1:1) & $94.00 \mathrm{~b}$ & 62.07 \\
\hline $\mathrm{T}_{5}=$ Chirata(1:1) & $92.33 \mathrm{bc}$ & 59.19 \\
\hline $\mathrm{T}_{6}=$ Garlic(1:2) & $94.33 \mathrm{~b}$ & 62.64 \\
\hline $\mathrm{T}_{7}=$ Neem(1:2) & $93.67 \mathrm{~b}$ & 61.50 \\
\hline $\mathrm{T}_{8}=$ Bishkatali(1:2) & $83.33 \mathrm{e}$ & 43.67 \\
\hline $\mathrm{T}_{9}=$ Allamanda(1:2) & $91.33 \mathrm{~cd}$ & 57.46 \\
\hline $\mathrm{T}_{10}=$ Chirata(1:2) & $89.67 \mathrm{~d}$ & 54.60 \\
\hline
\end{tabular}

Data presents the mean of three replications

Three hundred seeds were tested for each sample

Figure with common letters did not differ significantly at $5 \%$ level by DMRT

Table 3. Effect of plant extracts (1:1 and 1:2) on germination of rice seeds (Pajam)

\begin{tabular}{|c|c|c|}
\hline Treatments & $\begin{array}{c}\text { Seed } \\
\text { Germination } \\
(\%)\end{array}$ & $\begin{array}{c}\text { Germination } \\
\text { increase over } \\
\text { control (\%) }\end{array}$ \\
\hline $\mathrm{T}_{0}=$ Control & \multicolumn{2}{|c|}{$58.00 \mathrm{~g}$} \\
\hline $\mathrm{T}_{1}=$ Garlic $(1: 1)$ & $97.33 \mathrm{a}$ & 67.81 \\
\hline $\mathrm{T}_{2}=$ Neem(1:1) & $80.33 \mathrm{e}$ & 38.50 \\
\hline $\mathrm{T}_{3}=$ Bishkatali(1:1) & $91.67 \mathrm{c}$ & 58.05 \\
\hline $\mathrm{T}_{4}=$ Allamanda(1:1) & $80.00 \mathrm{e}$ & 37.93 \\
\hline $\mathrm{T}_{5}=$ Chirata(1:1) & $97.33 \mathrm{a}$ & 67.81 \\
\hline $\mathrm{T}_{6}=$ Garlic(1:2) & $95.33 \mathrm{ab}$ & 64.36 \\
\hline $\mathrm{T}_{7}=$ Neem(1:2) & $83.33 \mathrm{~d}$ & 43.67 \\
\hline $\mathrm{T}_{8}=$ Bishkatali $(1: 2)$ & $93.67 \mathrm{bc}$ & 61.50 \\
\hline $\mathrm{T}_{9}=$ Allamanda(1:2) & $75.67 \mathrm{f}$ & 30.46 \\
\hline $\mathrm{T}_{10}=$ Chirata(1:2) & $93.33 \mathrm{bc}$ & 60.91 \\
\hline
\end{tabular}

Data presents the mean of three replications

Three hundred seeds were tested for each sample

Figure with common letters did not differ significantly at $5 \%$ level by DMRT

\subsection{Effect of Plant Extracts on Seed-Borne Infection of Three Rice Varieties}

Among the plant extracts, best performance in terms of reducing per cent seed-borne infection was obtained through treating the seeds of variety Pajam with garlic extract at (1:1) dilution and chirata (1:1) which reduced $95.03 \%$ and $93.79 \%$ seed-borne infection, respectively and also increased seed germination by $67.81 \%$ over control. Neem (1:1), garlic (1:2), chirata (1:2) and bishkatali (1:1) extracts reduced $80.74 \%, 86.96 \%, 91.30 \%$ and $89.44 \%$ seed-borne infection and also increased germination by $38.50 \%, 64.36 \%, 60.91 \%$ 
and 58.05\%, respectively over control (Pajam) (Table 3 and Plate 1). In case of variety BR6, best performance in terms of reducing per cent seed-borne infection was obtained through treating the seeds with garlic extract at (1:1) dilution which reduced $91.46 \%$ seed-borne infection and also increased seed germination by $67.68 \%$ over control (Table 1 and Plate 2 ). In case of variety Joya, best performance in terms of reducing per cent seed-borne infection was obtained through treating the seeds with garlic extract at $(1: 1)$ dilution and neem (1:1) which reduced $88.89 \%$ and $81.28 \%$ seed-borne infection, respectively and also increased seed germination by $68.39 \%$ and $66.09 \%$, respectively over control (Table 2 and Plate 3).

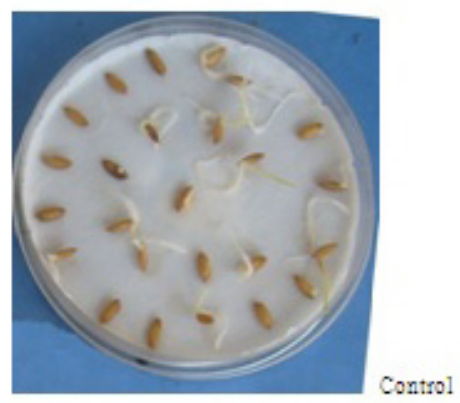

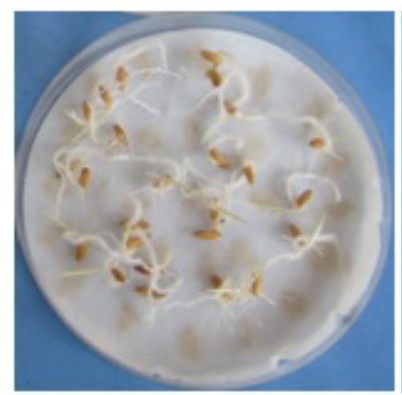

Garlic 1:1

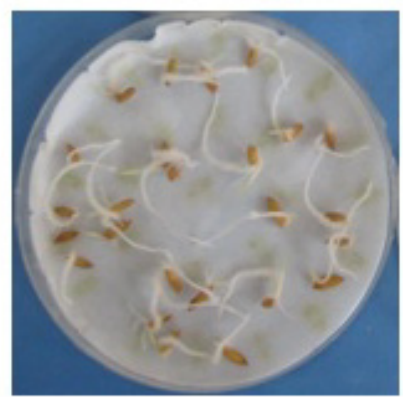

Chirata 1:1

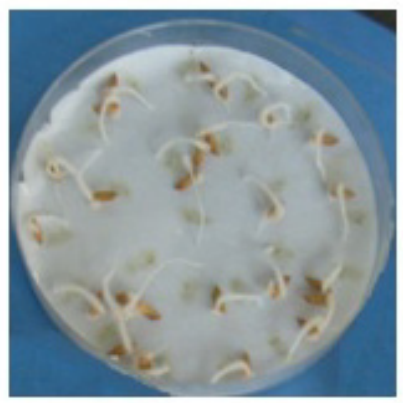

Neen 1:1

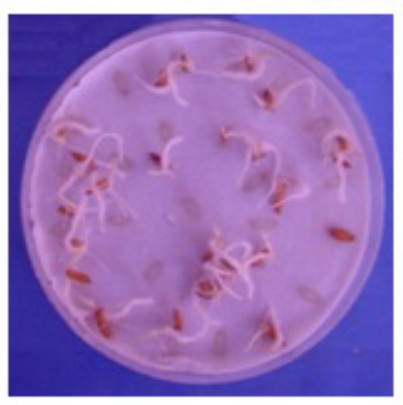

Chirata 1:2

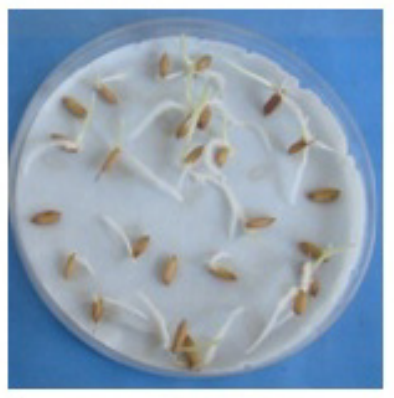

Nean $1: 2$

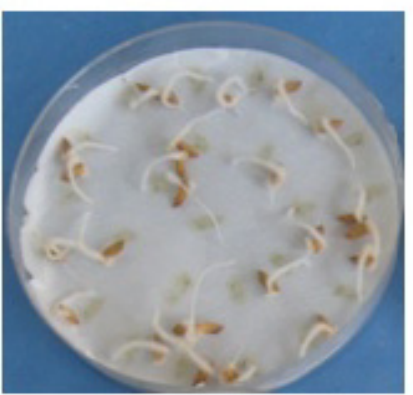

Garlic 1:2

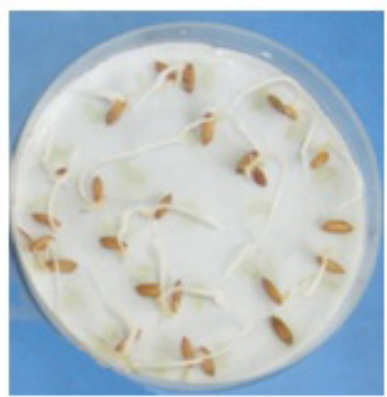

Bishkatali 1:1

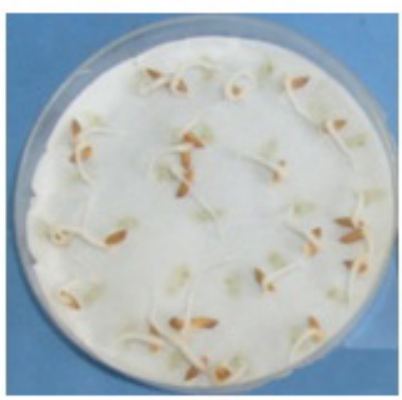

Allamandal: 1

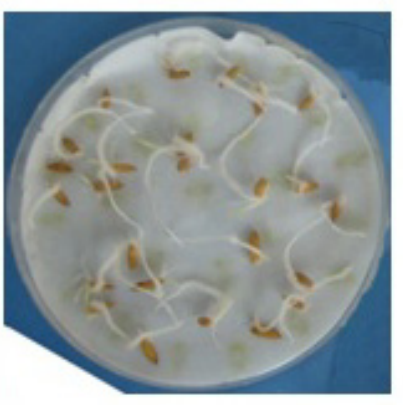

Bishlatali 1:2

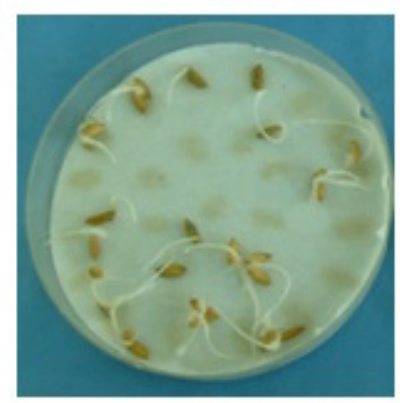

Allamanda 1:2

Plate 1. Effect of different plant extracts on Pajam seeds 


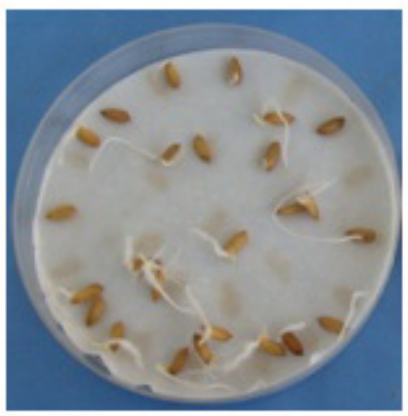

Contro]

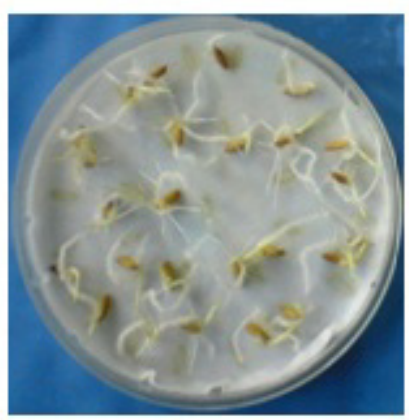

Garlicl:1

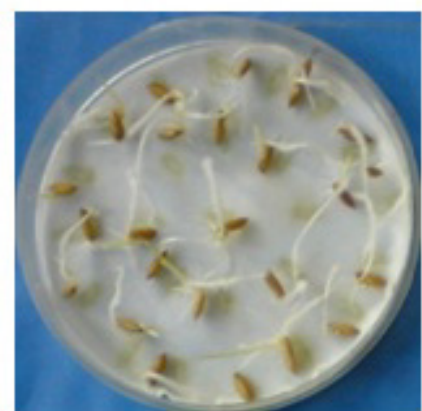

Garlic 1:2
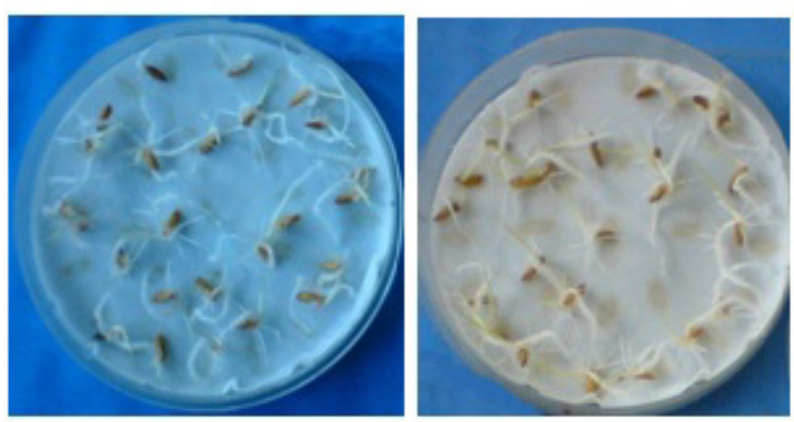

Neem 1:1
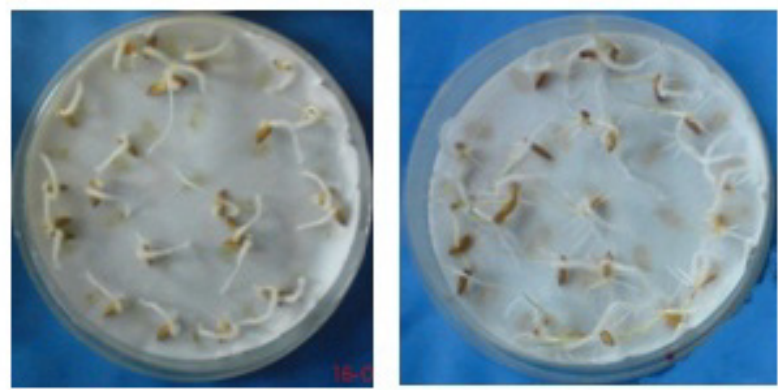

Bishkatali 1:1
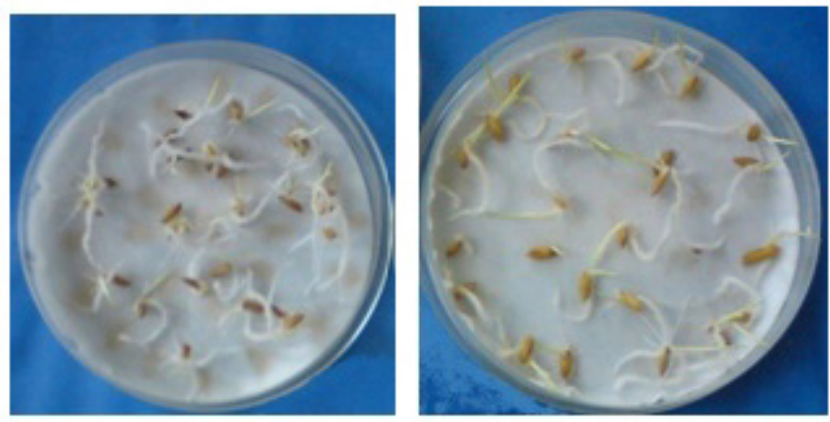

Chirata 1:1

Chirata $1: 2$
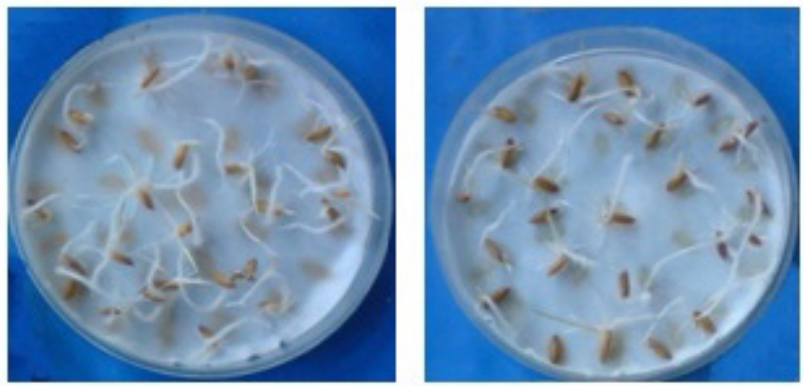

Allamanda 1:1

Plate 2. Effect of different plant extracts on BR6 seeds 


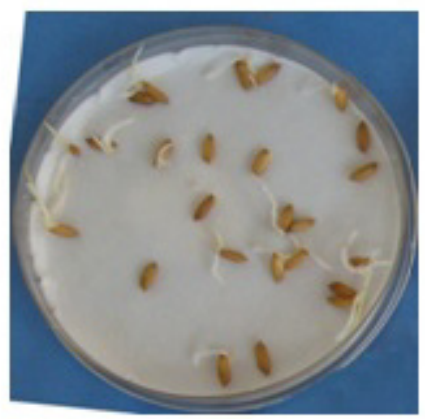

Control

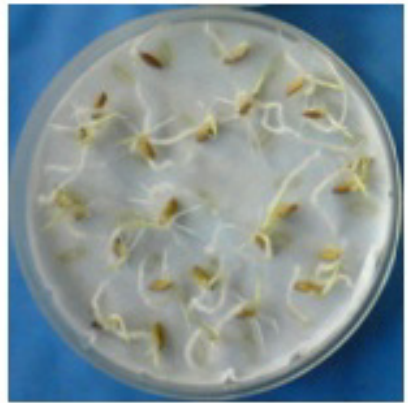

Garlic1:1

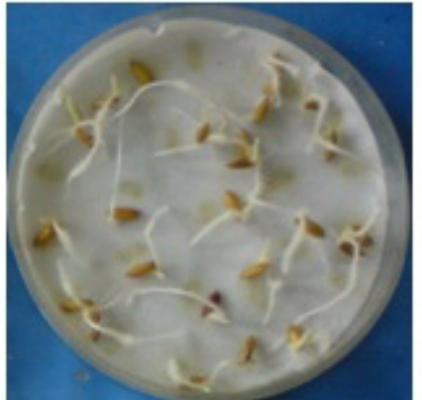

Garlic 1:2

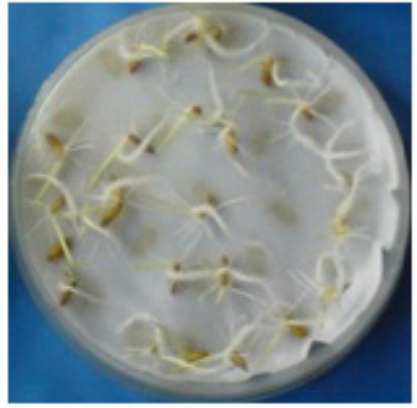

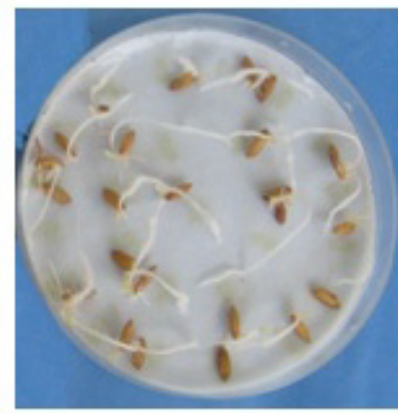

Neen 1:1

Neen 1:2

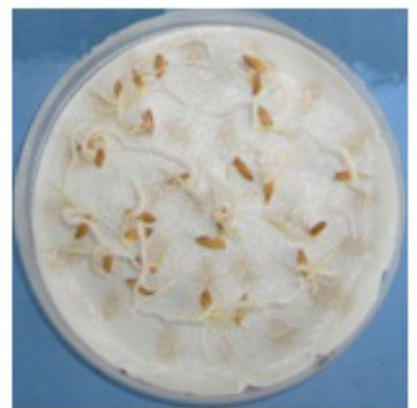

Chirata 1:

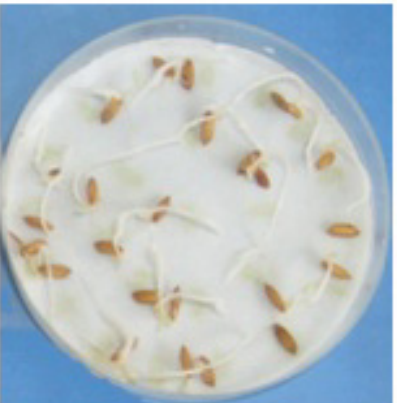

Chirata 1:2
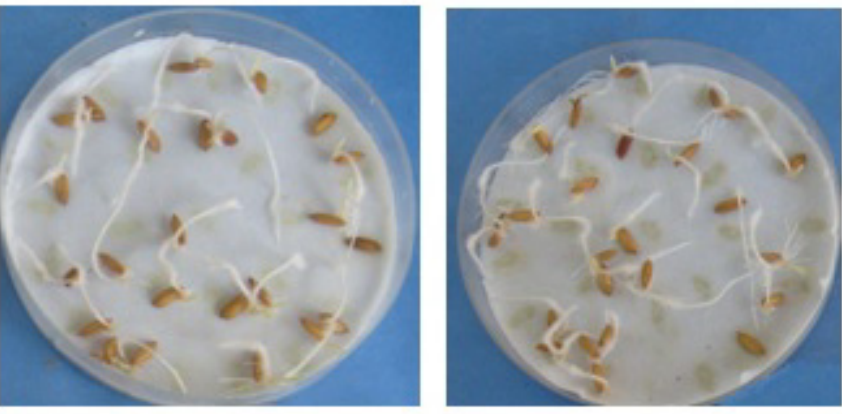

Allananda 1:1

Allamanda 1:2
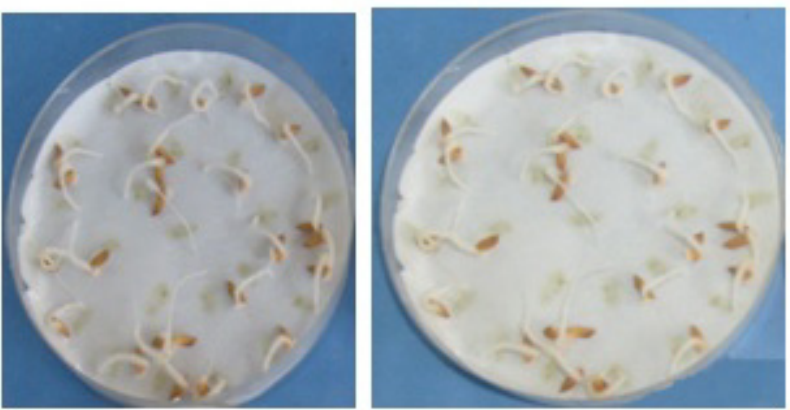

Bishkatali 1:1

Plate 3. Effect of different plant extracts on Joya seeds 


\section{Conclusion}

From the present investigation it is clear that seed-borne fungi are threat to health of rice seeds. Thus, situation demands that due attention should be paid to health status of rice seeds prior to sowing. Seed treatment may be a quick technique, applicable in this regard as it reduces or eliminates seed-borne fungi and also increase seed germination. Seed treatment with plant extracts is an eco-friendly measure in controlling seed-borne pathogens. Seed treatment with garlic extracts @ 1:1 dilution significantly increases seed germination of three varieties and also effectively controls the seed-borne fungi of rice. It was also found that neem extracts $(1: 1)$ and chirata extracts (1:1) also effective against seed-borne fungi. As chemical is hazardous to our ecology, serious threat to our terrestrial and aquatic species of animal, use of plant extract is essential for maintaining sustainable environmental condition. At present, when human population is crossing its limit, the destruction caused by different pathogens of crops is possing serious problem. The imbalance between populations arises and agricultural production creates shortage of food. Under this situation it is essential that we should aim at obtaining maximum production from our limited area. In these efforts, there is a need for matching the production technology with protection technology. If we continue putting our efforts only to production of crops without protecting them, the self-sufficiency in food will remain only a dream. So, we should practice seed treatment before sowing as a routine practice to achieve sustainable agricultural production. But the study of one season and only laboratory experiment is not sufficiently enough. This emphasizes the need of undertaking further comprehensive research with more varieties, plant extracts and field study for its confirmation.

\section{REFERENCES}

[1] Huda, M. Z. 2001. Regional development of irrigation technologies and its impact on food grain production in Bangladesh. M.S. Thesis, Department of Agricultural Economics, BAU Mymensingh, Bangladesh.

[2] BBS. 2008. Statistical Year Book of Bangladesh, Bangladesh Bureau of Statistics, Statistics Division, Ministry of planning, Government of People's Republic of Bangladesh, Dhaka, 2008.

[3] FAO. 2007. Production year Book. Food and Agriculture organization. Rome, Italy.

[4] Fakir, G. A., I. Hossain, M. U. Ahmad, M. Asad-ud-Doullah and M. Alam. 2002. Quality of farmer's Boro and T. Aman rice seeds collected before sowing from Bogra, Rajshahi and Rangpur Districts of Bangladesh. A paper presented in the Review and planning meeting of the rice seed health improvement (PETRRA) project, held on 21-22 April at BRRI, Gazipur, Bangladesh.
[5] Fakir, G. A. 2000. An annotated list of seed-borne disease in Bangladesh. Seed Pathology Laboratory. Dept. of Plant Pathology, BAU, Mymensingh. p.4 1.

[6] Danquah, O. A., S. B. Mathur and P. Neergaard. 1976. Fungi associated with discoloured rice seeds in Ghana. Ghana J. Agri. Sci. 9(3): 185-187.

[7] Sharma, H. L., H. S. Randhawa, A. Kapur and S. Singh. 1987. Seed discolouration in rice. Seed Research and Production unit 24(1): 37-41.

[8] Misra, A. K. and V. Dharam. 1991. Wild rice and it crosses, the alternative hosts of paddy grain discolouring fungi. Int. J. Trop. P1. Disease 9(1): 123-125.

[9] Sachan, I. P. and V. K. Agarwal. 1994. Effect of seed discolouration of rice on germination and seedling vigour. Seed Research. 22(1): 39-44.

[10] Fakir, G. A., I. Hossain, M. U. Ahmed, M. K. Anam, M. N. Alam and M. Rahman. 2003. Effect of ash, chalk powder and neem leaf on the quality of born rice seed stored in gunny bag, motka, plastic drum and tin. Proceeding of review and planning meeting of the Rice Seed Health Improvement Sub-project held at BRRI, Gazipur, Bangladesh during 21- -22 April, 2003.pp. 1-37.

[11] Savary, S., L. Willocquet, F. A. Elasegui, N. P. Castilla and P. S. Teng. 2000. Rice pest constrains in tropical Asia: quantification of yield loss due to rice pest in a range of production situations. Plant Dis. 84: 357-369.

[12] Bilgrami, K. S. and H. C. Dube. 1976. A Text Book of Modern Plant Pathology. Vikas Publishing House PVT, Ltd. New Delhi. pp.164.

[13] Assadi, P. and M. Behroozin. 1987. The effect of bulb extracts of onion and garlic on the mycelial growth of Fusarium spp., Sclerotium cepivorun. Iranian J. Plant Pathol. $23(1-4): 1-3$.

[14] Singh, R. H. and R. S. Dwivedi. 1987. Fungitoxicity of different plant Sclerotium rolfsii Sacc. Nat. Aca. Sci. Lelt. 10 (3): 8-91.

[15] Miah, A. T., M. U. Ahmed, N. R. Sharma, A. Ali and S. A. Miah. 1990. Antifungal activity of some plant extracts. Bangladesh J. Botany 19 (1): 5-20.

[16] Ashrafuzzaman, M. H. and A. R. Khan. 1992. Antifungal activity in vitro of some plant extract on Rhizoctonia solani. Bangladesh J. Sci. Res. 10 (2): 243-244.

[17] Hossain, I. and E. Schlosser. 1993. Control of Bipolaris sorokiniana in wheat with neem extracts. Bangladesh J. Microbial. 10 (1): 39-42.

[18] Fakir, G. A. and M. U. Ahmed. 1974. Microflora of freshly harvested rough rice grains of Tepiboro. Bangladesh Agril. Sci. Abs. 2: 160 .

[19] Mia, M. A. T. and S. B. Mathur. 1983. Study on seed mycoflora of rice in Bangladesh. Seed Res. 11 (2): 254-257.Mia, M. A. T. and S. B. Mathur. 1983. Study on seed mycoflora of rice in Bangladesh. Seed Res. 11 (2): 254-257.

[20] Basak, A. B., G. A, Fakir and M. A. U. Mridha. 1991. Mycoflora of chilli seeds obtained from different types of fruit rots. Chittagong Univ. Studies Part II. 15 (2): 11-17. 
[21] Rahman, M. M. 2002a. Effect of farmers storing processes in relation to seed quality and seed-borne fungi of rice (BR11). M.S. Thesis, Dept. of Plant Pathology, BAU, Mymensingh.p.52.

[22] Rahman, M. M. 2002b. Effect of storage containers under farmers condition on seed mycoflora and quality of Boro seed. M.S. Thesis, Dept. of Plant Pathology, BAU, Mymensingh. pp.25-40.

[23] Hossain, I., H. Mahamud and H. Ashrafuzzaman. 1997. Effects of plant extracts on fungi (Bipolaris sorokiniana and Rhizoctonia solani) and okra mosaic disease. Ecoprint 4(1): $35-42$.

[24] ISTA. 1976. International Rules for Seed Testing Association. Int. Seed test. Assoc. 31: 107-115.

[25] Rahman, G. M. M., M. R. Islam and M. A. Wadud. 1999. Seed treatment with plant extracts and hot water: a potential biophysical method of controlling seed-borne infection of wheat. Bangladesh J. Training and Development. 12(1-2): 185-190.
[26] Ahmed, M. F. 2002. Efficacy of some fungicides and plant extracts against Bipolaris oryzae. M.S. Thesis, Dept. of Plant Pathology, BAU, Mymensingh.

[27] Howlader, A. N. 2003. Effect of seed selection and seed treatment on the development of phomopsis blight and fruit rot of egg plant. An M.S. Thesis submitted to the Dept. of Plant Pathology, BAU, Mymensingh. pp. 40-68.

[28] Mondall, N. K., A. S. k. Mojumdar, A. Chatterje, J. K. Banerjee and S. Gupta.2009. Antifungal activities and chemical characterization of neem leaf extracts on the growth of some selected fungal species in vitro culture medium. Journal of Applied Sciences and Environmental Management 13(1):49-53.

[29] Khan, M. I. and R. Kumar. 1992. Antifungal activity of leaf extract of Neem on seed mycoflora of wheat. Indian J. Seed Abs. 15(7): 299.

[30] Rahman, M. 1992. Study on the seed-borne fungi and their control with Botanical and Chemical fungicides on five local Boro varieties of rice. M.S. Thesis, Dept. of Plant Pathology, BAU, Mymensingh. pp.81-82 